\title{
ARTICLES
}

\section{The Determinants of Committee Membership in Belgium and the Netherlands}

\author{
Tim Mickler ${ }^{*}$
}

\begin{abstract}
In this article I analyse whether differences in formal committee structures affect how parliamentary actors organise their work within them. I compare the allocation of members to specialised committees in the Dutch House of Representatives (Tweede Kamer) and the Belgian Chamber of Representatives (Kamer van Volksvertegenwoordigers/Chambre des Représentants) to test whether committee assignments are given more serious consideration when committees are strong. Despite many similarities, both parliaments differ in their internal institutional arrangements: committees in the Chamber of Representatives are, at least formally, considerably more powerful than those in the Dutch Lower House. The article uses the congressional theories of legislative organisation as heuristic devices to deduce several rationales of the assignment process. The role of parliamentary party groups is highlighted. The results indicate the presence of stable, reoccurring patterns in both parliaments. Even in the House of Representatives, where committees present lower opportunity structures, assignments are given due consideration.
\end{abstract}

Keywords: parliamentary committees, legislative organisation.

\section{The Determinants of Committee Membership in Belgium and the Netherlands}

Research on the institutional arrangements of parliaments suggests that the internal design affects legislative processes and outputs. A parliament's committee system is crucial in this regard. Parliaments around the world use committees for legislative review and to monitor government operations. It is conventional wisdom that a strong legislature is built on a strong internal committee system. There are several comparative studies on formal committee powers across parliamentary democracies (André, Depauw \& Martin, 2016; Mickler, 2017; Strøm, 1998; Zubek, 2015, 2020) which describe the great range of institutional arrangements across parliaments and investigate the causes of the variation.

\footnotetext{
* Tim Alexander Mickler is an assistant professor at the Institute of Political Science at Leiden
} University. Corresponding author: Tim Mickler at t.a.mickler@fsw.leidenuniv.nl. 
These differences also raise a question regarding their consequences: do different institutional arrangements affect how actors in parliament utilise committees to pursue their goals? When committees are strong, and individual members of parliament (MPs) and parliamentary party groups (PPGs) can significantly impact parliamentary output through them, there is a greater incentive to perceive them as an important arena. Hence, actors should carefully consider the potential effects of the division of labour in committees. One of the main aspects where this should be visible is the assignment of MPs to committees. Committee seats are scarce resources that allow MPs to engage in advertising, credit claiming and position-taking (Mayhew, 1974). Suppose committee membership will enable MPs to have a powerful impact, then who sits on a committee 'matters'. Conversely, when committees are weak and ineffective, they present lower opportunity structures. The focus should then shift from committees to other venues, such as the plenum, and decisions on committee assignments should be given less consideration. Whether this holds empirically and different strategies can be observed, however, has been hardly studied.

This article addresses this question by comparing committee assignments in the Lower Houses of the two 'Low Countries': the Dutch House of Representatives (Tweede Kamer) and the Belgian Chamber of Representatives (Kamer van Volksvertegenwoordigers/Chambre des Représentants). The main research question is, what factors explain committee assignments in the lower chambers of the Low Countries? A comparison of these countries is well-suited for investigating the effect of different institutional arrangements. Although differences between the countries exist, such as the complex structure of interlocking competencies in Belgium (Deschouwer \& Reuchamps, 2013), Belgium and the Netherlands are typical consociational or consensus democracies (Lijphart, 1977). Both countries have similar electoral systems (Nagtzaam, 2019), fragmented party systems (Arwine \& Mayer, 2013; De Winter, Swyngedouw \& Dumont, 2006) and similar experiences with multiparty governments (Timmermans \& Moury, 2006). Yet despite their geographical proximity, common history and shared experience with social developments (Andeweg, 2019), the Lower Houses have established different internal institutional arrangements. Although both establish a system of permanent committees, the House of Representatives scores relatively low in comparative analyses of committee strength, e.g. ranking 21st out of 31 in André et al. (2016, similar in Mickler, 2017; Zubek, 2020). Committees in the Chamber of Representatives are more powerful (ranked 9th in André et al., 2016).

This article contributes to the literature that analyses how, within parliaments of parliamentary democracies, who is selected to sit on which committees and with what consequences. Previous studies have suggested a range of factors that explain the process, such as electoral rules and constituency demands, particularly in committees that allow MPs to cater to the interests of voters (Chiru, 2019; Gschwend \& Zittel, 2018; Raymond \& Holt, 2018; Raymond \& Juárez, 2019). MPs' expertise in a committee's jurisdiction was linked to assignments in many institutional contexts (Chiru, 2019; Giannetti, Pedrazzani \& Pinto, 2019; Mickler, 2018a, 2019). Female MPs were shown to be overrepresented in committees that deal with 'feminised' or low-status policy areas (Baekgaard \& Kjaer, 
2012; Chiru, 2019; Espírito-Santo \& Sanches, 2020; Goodwin, Holden Bates \& McKay, 2020; Murray \& Sénac, 2018; Pansardi \& Vercesi, 2017), although there is an ongoing debate on whether this is the result of self-selection or discrimination. Additionally, the 'structuring' hand of the PPG leadership was demonstrated in some studies (Giannetti et al., 2019).

The article proceeds as follows. Section 2 elaborates on the committee systems of the two parliaments to clarify the distinction between weak and powerful committees. Section 3 presents the theoretical framework, which comprises the congressional theories of legislative organisation. Section 4 describes the data, followed by a summary of the main results.

\section{The Cases: Committees in the Lower Houses of the Low Countries}

Both Lower Houses rely on various committees in their daily operation. The Rules of Procedure (RoP) of the Chamber of Representatives distinguishes between permanent committees (vaste commissies/commissions permanente), temporary, special (rules described in Chapter VIII, RoP) and advisory committees (adviescomité/ comités d'avis, Chapter X, RoP). Temporary committees may be set up to examine particular bills or proposals (Art. $157 \mathrm{RoP}$ ). The term 'special committees' refers to a wide range of committees. The RoP stipulate the establishment of some (see Arts. 2, 121, 142, 149, 150, 151, 160, 172 \& 180). Additional examples include the special committee set up in 2020 to examine the structural impact of Belgium's colonial past. At all times, committees of inquiry can be established to investigate an issue (see Staelraeve, 2003 for an extended discussion). Advisory committees are a distinctive type and are used for the areas of European Affairs (see Art. 68), social emancipation (Art. 69) and technological issues (Art. 70). Each advisory committee has specific membership regulations. For example, the advisory committee on European Affairs is a joint committee with ten members of the European Parliament who are elected in Belgium. The RoP in the Dutch House of Representatives allow for the establishment of permanent (vaste), temporary (tijdelijke) committees (established for a specific topic and have limited duration), as well as committees of inquiry (enquêtecommissies). Generally, the same 'housekeeping' committees, i.e. those that deal with matters pertaining to day-to-day management, are established in both parliaments, although a slightly different terminology is used.

\subsection{Permanent Committees: Jurisdiction and Size}

Of primary importance for the legislative work and government control is the system of permanent, topic-specific committees established in both parliaments after each election. There are some notable differences between those types of committees in the two parliaments. The first concerns committees' size. Committees in the Chamber of Representatives comprise 17 members (Art. 19(2), Rules of Procedure Chamber of Representatives, 2020). Permanent committees in the Dutch Lower House had, until the most recent election in 2021, 26 members and 26 substitute members. However, their size was increased in the legislative period 
following the election: each of the 15 permanent committees now comprises 34 members and 32 substitutes, which is remarkable for a parliament of 150 members.

Committees in both Lower Houses reflect the composition of the plenum proportionally. Given that, owing to the electoral system in both countries, some parties are represented with very small numbers, special rules exist. In Belgium, if there are fewer than five MPs from a party, they are not considered a PPG (Art. 11). This restricts their right to have a seat on a committee. Often, these MPs are assigned without the right to vote. In the Dutch Lower House, even MPs elected as the only person on their list will form a 'separate faction' (afzonderlijke fractie) and enjoy the same rights as other PPGs. Therefore, the increase in the number of seats per committee in the House of Representatives is not surprising, given that in the 2021 Dutch general elections 17 parties entered parliament (three with $1 \mathrm{MP}$ ).

A second general aspect of committees refers to the policy areas that they cover. To maximise the efficiency of committees, they should correspond to ministerial portfolios as closely as possible. In the House of Representatives, each ministerial portfolio must have a counterpart in the form of a permanent committee (see $\S 7$, Rules of Procedure House of Representatives, 2021). ${ }^{1}$ In the past, the parliament also established a general committee (algemeen commissie) for ministers who do not head a particular ministry (Dutch: Ministers zonder portefeuille). However, these were abolished in the course of a revision of the RoP in 2021. A provision was entered that the House may set up standing committees for one session for the area of responsibility of these ministers or state secretaries.

In the Chamber of Representatives, the jurisdiction of the permanent committees is determined by the president of the House, taking into account the opinion of the conference of presidents. In recent legislative periods, committees frequently shadowed different ministerial portfolios or had overlapping policy areas. For example, the permanent committee for Business, Science Policy, Education, National Scientific and Cultural Institutions, Self-employed and Agriculture (established in the 50th-54th legislative period) shadowed (in the case of the Michel I government, starting in 2014) the Minister of the Middle Class, Small and Medium Enterprises, Self-employed and Agriculture, as well as the Minister of Employment, Economy and Consumer Affairs. It was also responsible for areas of cultural and educational policy that remain the federal government's responsibility. This less clear congruence between committees' jurisdiction and ministerial portfolios limits, ceteris paribus, their ability to fulfil their tasks efficiently.

\subsection{Redrafting Abilities}

Beyond size and correspondence to ministerial jurisdiction, a significant aspect of committees' 'opportunity structures' is determined by their formal powers. One aspect concerns the authority of permanent committees to rewrite bills. Committees in the Chamber of Representatives generally have more abilities than their Dutch counterparts. In Belgium, committees can alter the text of a bill by moving amendments. After the committee stage has ended, committees submit the redrafted 'clean' bill with a report to the plenary session. This makes them rela- 
Table 1 Committees' 'policing power' in the Lower Houses of the Low Countries

\begin{tabular}{|c|c|c|}
\hline & $\begin{array}{l}\text { Belgium: Chamber of Represen- } \\
\text { tatives }\end{array}$ & NL: House of Representatives \\
\hline $\begin{array}{l}\text { Rights to invite/ } \\
\text { compel wit- } \\
\text { nesses? If so, } \\
\text { whom? }\end{array}$ & $\begin{array}{l}\text { Invite ministers, civil servants, exter- } \\
\text { nal experts. Only inquiry committees } \\
\text { can compel. }\end{array}$ & $\begin{array}{l}\text { Invite government and external } \\
\text { experts. Invitation of civil servants } \\
\text { with permission of ministers. Only } \\
\text { inquiry committees can compel. }\end{array}$ \\
\hline $\begin{array}{l}\text { Openness com- } \\
\text { mittee hearings }\end{array}$ & Public, but private sessions possible & Public, but private sessions possible \\
\hline $\begin{array}{l}\text { Rights to ask for } \\
\text { documents }\end{array}$ & Yes, unrestricted & Yes, unrestricted \\
\hline Nr own staff & $\begin{array}{l}\text { Two 'level I' officials per committee } \\
+5 \text { assistants (level } 2 \text { ) }\end{array}$ & Between 4 and 9 per committee \\
\hline
\end{tabular}

Source: Own data.

tively strong from a comparative perspective. Committees in the Chamber of Representatives can also initiate bills.

Committees in the Dutch House of Representatives cannot rewrite or initiate bills and can also not include amendments. During the committee stage, committee members usually provide their views on the bill in a written report, followed by a written response from the government (Bovend'Eert \& Kummeling, 2010, p. 225). At the end of these exchanges, a final report is drafted for consideration in the plenary session. Of course, oral debates occur, but these are mostly reserved concerning debates about plans for future policies. If, on the basis of the discussion in the committee, an MP or groups of MPs decide to introduce a motion, then committee members themselves cannot vote on it. Instead, voting must take place in the plenary meeting. In such cases, the report of the committee consultation is placed on the plenum's agenda so that MPs can introduce and vote on motions. Votes are preceded by short debates, so-called two-minute debates (Dutch: tweeminutendebat ${ }^{2}$ ).

\subsection{Policing Powers}

A final point concerns committees' capacity to acquire information. Table 1 summarises several factors that are often connected to committees' ability to control the government. Based on this, the formal policing powers are similar (see also longitudinal analyses by Zubek (2020) and L. W. Martin \& Vanberg (2020)). However, it should be noted that the dedicated staff in the House of Representatives is a more recent development. Committees had, until 2017, no own staff but were supported by a central bureau.

Despite these commonalities in policing powers, committees in the House of Representatives are, at least formally, considerably more limited in their redrafting ability than committees in the Belgian Chamber of Representatives. Recent reforms of the RoP in the Netherlands have not put committees on an equal foot- 
ing with their Belgian counterparts. This gives rise to the question whether committee allocation in the two countries follows different logics. To deduce testable hypotheses, the following section elaborates on the theoretical framework for the analysis.

\section{Theoretical Framework: Analysing Committee Assignments}

To analyse committee allocations in the two Lower Houses, it is crucial to clarify the role of PPGs in the assignment process. Beyond studies in the US context (Congress/State legislatures), in which the influence of partisan politics is disputed, PPGs in parliamentary democracies are essential gatekeepers in the assignment process (for an overview, see S. Martin, 2014; S. Martin \& Mickler, 2019). In the two analysed parliaments, similar to many other parliaments, seats in committees are assigned to PPGs, which subsequently allocate their members to committees. This implies that individual MPs cannot decide their committee assignments entirely by themselves (i.e. self-select to committees). Yet, PPG leaders do not simply 'dictate' committee assignments. The available evidence in many countries suggests that the preferences of MPs are taken into account when decisions on committee assignments are to be made. In very few countries or specific parties do PPG leaders tend to decide autonomously.

To explain committee assignments, several theoretical frameworks have been proposed. Of primary importance is a group of rational choice theories developed initially to analyse the legislative organisation of the US Congress. Given the 'special' nature of the legislature, the theories are usually not transferred directly. Instead, analyses in other parliaments have, rightfully, acknowledged the role of PPGs in the process but then used the fundamental predictions of these theories as 'rationales' to formulate expectations on what drives the differentiation processes. These suggest, respectively, that committee assignments are made to (1) serve special interests outside the parliament (distributive perspective, see Shepsle (1978)), (2) bring informational benefits to reduce uncertainty (informational perspective, see Krehbiel (1992) or (3) promote the interests of the PPG leadership (partisan perspective, see Cox \& McCubbins (1993).

There are alternatives to these 'imported' perspectives, most notably the model by Hansen (2019), which builds on the literature on cabinet governance in parliamentary systems. This research demonstrated that parties use legislative instruments and allocate government portfolios strategically in coalition situations. It is argued that the same logic applies when committee seats are distributed. Results for the Danish parliament indicate that parties strategically underand over-represent committee chairs and seats. Although this perspective is an important addition to the theoretical toolbox, the two parliaments have clear rules about committees' size and composition, limiting the model's applicability.

In the Chamber of Representatives, strategic 'stacking' is not possible because the number of seats per PPG is fixed across committees (based on proportional representation, see Art. 158 of the RoP). The Rules of Procedure of the House of Representatives do not stipulate the number of seats per PPG in committees 
(Art. 7.11 states that the Speaker decides on the size of committees, ${ }^{3}$ the House can veto). Still, in the past, the same (proportional) distribution was used across all permanent committees. Additionally, these decisions are taken before the allocation of government portfolios is clear. Changes in committee chairs are common once the government is formed, but, usually, no changes are made in the proportionality. In view of this, the article draws on the congressional theories only.

\subsection{Deducing Hypotheses}

The informational theory highlights the uncertainty that actors in parliament face about the consequences of policies (Gilligan \& Krehbiel, 1990, p. 533). It views committees as means to ensure the efficiency of the legislative process. Applied to committee assignments, the informational rationale predicts that the expertise of MPs is a crucial factor in decisions on allocations, as MPs with expertise in an area can specialise at low cost. It is a valid strategy for PPGs to draw together MPs with relevant knowledge to aggregate information and alleviate existing uncertainty to guarantee an efficient decision-making process.

Hypothesis 1: MPs with relevant prior knowledge in a committee's jurisdiction are more likely to be assigned to the committee.

A further prediction concerns the reassignment of incumbent MPs to committees. A positive effect suggests that MPs continue to deepen their expertise by staying on the same committee in successive legislative periods. However, the treatment of committee experience as an indicator of an informational rationale needs to be qualified. If the results show that assignments cannot be explained by MPs' relevant prior knowledge in a committee's jurisdiction but instead support factors linked to the distributive and partisan rationales, this would indicate that MPs cluster in committees not on their ability to specialise at low cost. The analysis will account for this.

Hypothesis 2: Incumbent MPs who served on a committee in the previous legislative period are more likely to be assigned to the committee.

The distributive theory argues that re-election is the main driving force of legislative organisation and that internal structures are set up to maximise MPs' re-election goals. Committees are crucial because they allow MPs to work on issues that are important to their constituents. The distributive rationale of committee assignments suggests that MPs will join committees that allow them to serve outlying interests best. In the US Congress, this has been tested using constituency demands (e.g. MPs from rural districts seek assignments to the agriculture committee, see Adler \& Lapinski, 1997). However, it is challenging to conduct similar tests in the two Lower Houses of the Low Countries. In the Netherlands, it is impossible to match constituency characteristics to MPs owing to the presence of only one single national district. In Belgian federal elections, the country is subdivided into multi-member constituencies (20 during the 1999 elections, 11 in the 
elections after 2003), but these are hardly comparable to their US counterparts. MPs in Belgium are very limited to deliver pork-barrel projects or deliver federal funds to local districts.

Instead of constituency characteristics, this analysis tests a distributive rationale using MPs' connections to organisations outside parliament (see Mickler, 2018b; Yordanova, 2009). Although this is a departure from the congressional argument, the same logic applies: if, disproportionally, MPs with relevant connections to organisations outside parliament that have a stake in the committee's policy area cluster in committees, then the internal subunits of the legislature comprise MPs who are driven by external concerns.

Hypothesis 3:MPs who have ties to outside organisations that are active in a committee's jurisdiction are more likely to be assigned to the committee.

A final set of hypotheses are based on the partisan theory of legislative organisation (Cox \& McCubbins, 1993). When applied to committee allocations, hypotheses are often set up to test whether specific characteristics of MPs increase the likelihood of being assigned to committees whose jurisdiction concerns an important issue domain of the PPG. In those committees, the electoral faith of most of the MPs is affected, which is why the influence of the leadership to influence compositions will be most clear. Three factors might be important in this regard. A first strategy is to 'reserve' seats on important committees for MPs who are placed higher on the party list. The underlying logic is that assignments help candidates with a strong electoral profile to maximise their votes.

Hypothesis 4: MPs who are placed higher on the party list are more likely to be assigned to committees whose jurisdiction concerns an important issue domain of the party.

A second partisan hypothesis tests the influence of MPs' ideological closeness to the PPG on the chances of being assigned to an important committee. Doing so implies that the PPG leadership uses assignments as a reward to extract partisan benefits for MPs who are closer to the PPG or punishes those who are not. It also corresponds to the prediction of the partisan theory that the composition of committees that are dealing with important areas for a PPG will be more moderate, rather than clustering 'extreme' MPs.

Hypothesis 5: MPs who are ideologically closer to the PPG are more likely to be assigned to committees whose jurisdiction concerns an important issue domain of the party.

Another factor used to test the partisan rationale is whether the number of legislative periods can be linked to the assignment to important committees. If senior MPs are disproportionally assigned to committees that are important for a party, and others are withheld from serving on them, this would imply a 'structuring' hand of the PPG leadership. 
Hypothesis 6: More senior MPs are more likely to be assigned to committees whose jurisdiction concerns an important issue domain of the party.

These hypotheses disentangle various factors that might structure the assignment process. As suggested in the introduction, the comparison of the two countries is made to investigate whether committee assignments in a formally weak system (the Netherlands) are given less consideration than assignments in a strong committee system. Time is a scarce resource within parliaments. When committees do not 'matter' (formally), they present lower opportunity structures for individual MPs and PPGs. In these cases, it might be rational to shift the focus to other venues and treat committee assignments with less attention. This leads to the formulation of the following hypothesis:

Hypothesis 7: The effect of factors concerning committee assignments will be weaker in the House of Representatives than in the Chamber of Representatives.

\subsection{Operationalisation}

Committee membership (full and substitute members): The dependent variable measures membership of a committee and is split into being assigned as a full member or substitute member. Arguably, full members are of primary interest for this article. However, analysing substitute members can test whether the same allocation principles are applied across the two groups. In both chambers, changes to the membership of committees are listed in the minutes of each plenary sitting. The minutes of the Chamber of Representatives were obtained from www.dekamer.be. For the House of Representatives, minutes were obtained from www.officielebekendmakingen.nl, the central access point to all information about government organisations. For both full and substitute members, the final variables measure initial assignments at the beginning of the legislative period, including transfers during the legislative period.

In the Netherlands, I include all legislative periods from 1998 to 2017. All committee assignments from the 50th (1999-2003) to the 54th (2014-2019) legislative period are included for Belgium. I include only specialised committees, i.e. those who work on specific policy areas and usually have a ministerial counterpart (or cluster policy areas from several ministries). In the case of the Chamber of Representatives, the same committees were consistently established in the analysed legislative periods. ${ }^{4}$ In the Netherlands, reshuffling of policy areas occurred more frequently after elections. Appendix 1 and 2 contain an overview of all included committees.

Prior education/occupation: The informational logic of committee assignments predicts that MPs will be allocated to committees if they can specialise at a low cost in a policy area. MPs' prior education and occupation are essential sources of knowledge in this regard. Information on MPs' educational and occupational backgrounds was obtained from the personal profiles on the parliamentary websites (BE: www.dekamer.be; NL: www.tweedekamer.nl and the Parliamentary Documentation Centre). For the analysis, prior education and occupation are 
treated as two variables. The split into two variables has an analytical advantage: while educational backgrounds are often broader (e.g. many MPs have a background in the social sciences), previously held occupations are usually more specialised.

All available prior education and occupation data were coded using the ISCO-08 classification scheme (International Labour Office, 2012). ISCO codes were then matched to policy areas of committees. The general guideline was whether a background allows an MP to specialise in a policy area at a lower cost than an MP who does not have a similar background. To illustrate, teaching professionals (ISCO-08 group 2300) were treated as having relevant knowledge for committees dealing with education policy, those who worked in farming (ISCO-08 group 6100) for committees that deal with agriculture, etc. No distinctions were made between skill levels; e.g. managers, professionals or associate professionals were treated equally.

Some ISCO groups deserve special attention, in particular those with a legal background. While one could argue that those MPs can specialise in all policy areas, I opted to code these MPs only for those committees that deal specifically with legal issues (e.g. legal affairs or constitutional reform). This was done to treat all MPs equally and to prevent an abundance of positive codes that would make it difficult to disentangle the effect of specialisation.

Committee experience: Data on committee membership in previous legislative periods is based on this article's data set of committee assignments. In the case of the Chamber of Representatives, this was straightforward given that the same committees were established throughout the analysed period. In the House of Representatives, reshuffling and merging committees are more common. MPs were coded as having committee experience if a committee was split into different committees or merged into one committee. Only the immediately preceding legislative period was used for this variable. I exclude committee experience in the 50th legislative period in Belgium owing to missing data.

External interests: To indicate ties to outside groups, I coded official functions (e.g. board membership) of all MPs. The information for Belgian MPs is available online (Belgian Court of Audit, 2020). Unfortunately, no data are available for the 50th legislative period. For the Netherlands, data for the 2012 legislative period are available online (Tweede Kamer, 2021). For previous legislative periods, data were obtained from the secretariate of the parliament. Official functions were then matched to the committees' jurisdiction. Examples of relevant additional functions include board members of the Belgian Road Safety Institute (committee dealing with traffic) or, in the case of the committee of agriculture, the Regional Centre for the Valorisation of Agricultural Production (Centre Régional de Valorisation de l'Agroalimentaire).

Relative list position: The first partisan hypothesis predicts that higher placed candidates are disproportionally assigned to more important committees. Both countries use a list system. For the election of the Chamber of Representatives, the country is divided into 11 districts with varying district magnitude. For the House of Representatives, the country is, effectively, treated as a single district when it comes to the distribution of seats to parties ${ }^{5}$ (see for an extended discus- 
sion Nagtzaam, 2019, p. 10ff). The list position of Dutch MPs was based on the official records of the Dutch Electoral Council (1998, 2002, 2003, 2006, 2010, 2012). Data on the list position of Belgian MPs were obtained from Nagtzaam (2019). ${ }^{6}$ Data for the 50th legislative period are not available online ${ }^{7}$ and are missing from the analysis. To consider the size of the PPG, the relative list position value was calculated as follows: (list position of MP - 1)/(total number of seats of PPG-1)

Ideological distance to PPG mean: An additional hypothesis tests the effect of ideological proximity. MPs' positions are usually measured via voting behaviour, surveys or by inferring positions using speeches. Although research in the USA suggested a relationship between committee assignments and party-loyal voting (see, e.g., Leighton \& Lopez, 2002), the high level of voting unity in the two analysed countries and the generally rare use of roll-call votes make this variable unsuitable. Relying on surveys requiring MPs to place themselves on an ideological scale is also impossible owing to low response rates and missing surveys for several legislative periods. Instead, I estimate MPs' positions on the basis of their speeches using the computerised content analysis method Wordscores (Laver, Benoit \& Garry, 2003). Speeches from all MPs in the analysed legislative periods were obtained from the minutes of the plenary sessions.

The situation in Belgium is more complicated because of the multi-language nature of the parliament and the fact that the parliament's minutes list a speech in the language in which it was given. All speeches were translated into the same language using a Python script that relies on the Google Translation API to allow for a meaningful analysis. Although the occurrence of minor translation errors cannot be ruled out, grammatical errors that change the sentence structure will not affect the estimates, given that Wordscores analyses word frequencies. However, the variable should, in any case, be interpreted with these limitations in mind.

After translating the speeches, I calculated reference files that contain all speeches by MPs of a PPG in a legislative period. For government parties, this includes speeches by ministers and state secretaries. Subsequently, all MPs were scored against these reference files. The estimations were done using the quanteda package in R (Benoit et al., 2018). The final score for each MP is the difference between the PPG mean and their estimated Wordscores score, thus providing a sense of how much an MP deviates from their PPG in speeches.

Seniority: The number of legislative periods was based on MPs' profiles.

Importance of committees' jurisdiction: To test whether a difference exists in assignments to committees whose areas concern a central issue domain of the party, an indicator of the relative importance of a committee is required. Following the literature on issue saliency, which highlights the strategic choice of parties to emphasise topics in election campaigns (Wagner \& Meyer, 2014), I measure the importance of a committee in terms of saliency. For each committee, I added the score of relevant codes from the Manifesto Project (Volkens et al., 2020) data for each election. This indicates how much emphasis a party places on topics that are connected to a committee's jurisdiction. A special case was committees that deal with the budget. Owing to their role as the public spending watchdog, those 
committees received the highest ranking in terms of saliency. The overview of all committees and their respective Manifesto Project codes are available from the author on request. After calculating the relevant emphasis per policy area, all committees were ranked from ' 1 ' to the maximum number of committees in the analysed legislative period (highest value = highest saliency). The face validity of this approach is high. Highly salient topics across all parties include economic issues as well as internal affairs, but notable differences occur; for example, environmental issues score higher for Green parties than for other parties.

Gender: I include gender as a control variable to test whether female MPs are less likely to serve on highly salient committees. The gender of all MPs was obtained from their profiles.

\section{Results}

A multiple membership multilevel model was used to analyse the data (Beretvas, 2011; Browne, Goldstein \& Rasbash, 2001). These models are appropriate given the nested hierarchical structure (i.e. MPs clustered in committees). Random intercepts were entered for MPs, parties, committees and legislative periods if multiple legislative periods were analysed. ${ }^{8}$ Given that the same committees were established during the five analysed legislative periods in Belgium, all legislative periods were analysed in the same model by including a random intercept for the legislative period. A separate model was estimated for the 50th legislative period because data for external interests and list positions were unavailable. Each legislative period in the House of Representatives is analysed separately because of the reshuffling of committees' jurisdictions.

Per analysed parliament/legislative period, four models were estimated: full members (including transfers) without committee experience (Model 1) and with committee experience (Model 2), as well as substitute members (including transfers) without committee experience (Model 3) and with committee experience (Model 4). The models were estimated using the lme4 package in R (Bates, Maechler, Bolker \& Walker, 2015). The detailed results are presented in the appendix (Table 2, 3, 4 and 5). For the discussion, I will elaborate on the effects of the main variables using odds ratios (exponentiated coefficients) to demonstrate the strength of association between the factors and being assigned to a committee. Figure 1 shows the odds ratios of all variables, including 95\% confidence intervals for full members. Figure 2 presents results for substitute members. I include a vertical line at 1 to facilitate the interpretation of significance.

One of the main aims of the comparison was to test whether assignments in a formally weaker committee system are given less consideration (Hypothesis 7) than assignments in a 'stronger' committee system. If so, the results for the House of Representatives should be less stable or indicate weaker effects. This prediction is not supported concerning full members (Figure 1). In both parliaments and across all analysed legislative periods, clear patterns are visible. The results suggest that relevant prior education or prior occupation increases the chances of being assigned to a committee. If a matching prior occupation is pres- 
ent, the odds of being assigned to a matching committee increase, on average, with 1.96 in the Netherlands and 1.76 in Belgium (Model 1). Even though at least formally, committees in the House of Representatives were considered weak in comparative studies, the informational rationale of committee assignment for full members is supported. The strong effect of this variable is noteworthy in combination with the result for committee experience (Model 2, see the right plot in Figure 1). Across the 20 years of analysed committees, the odds of being reassigned to a committee are much greater for those who have served on a committee in the previous legislative period, suggesting that MPs further deepen their expertise.

Interestingly, while a clear assignment logic supporting the informational rationale is also present for substitute members in the Chamber of Representatives, no consistent effect exists for the House of Representatives (see Figure 2). Earlier research on the Dutch parliament has highlighted the special nature of substitute members. In the Dutch parliament, substitute members and full members are 'paired' (a full member can only be substituted with a particular substitute member). The main task of substitutes is to be present during meetings that schedule the agenda for the upcoming weeks (Dutch: procedurevergadering). During interview rounds in the past, several interviewed MPs were even unsure which committee they belong to as a substitute (Mickler, 2017). In the Chamber of Representatives, the evidence suggests that substitute membership is given more consideration. The same factors matter for the assignment of full and substitute members.

The evidence for a distributive rationale of committee assignments, tested via connections to outside organisations, is mixed. The variable passes the $10 \%$ and $5 \%$ significance threshold in some legislative periods for the House of Representatives, but the effect is weaker and less consistent compared with prior education and occupation. In the Chamber of Representatives, connections to outside organisations do not increase the odds of being assigned to a corresponding committee. Looking more closely into the data indicates great variation between committees. There are some committees (most notably Defence, Foreign Affairs, Justice) in which very few MPs have relevant connections. Across all committees, looking at those MPs who have a link to an organisation, only around 1/5 of MPs serve on the corresponding committee. It is, however, difficult to conclude whether PPGs actively avoid such connections or whether MPs themselves do not seek such assignments. Further qualitative research is needed to investigate the causal mechanism in depth.

None of the factors that relate to the PPG leadership's 'structuring' hand consistently increase the odds of being assigned to highly salient committees, either for substitute members or for full members. Although earlier interviews with MPs in the House of Representatives suggested that a higher list position sometimes solves intra-PPG conflicts, there are no general patterns of those being closer to the top of the list being disproportionally assigned to more salient committees. Likewise, no clear pattern is visible concerning parliamentary seniority or ideological closeness. Relatively high turnover rates characterise both parliaments. In their study on parliamentary careers of Belgian MPs since 1831, Verle- 
den and Heyneman (2008) show a decline in parliamentary experience since the middle of the previous century. This decline was further exacerbated after 1995 (Verleden \& Heyneman, 2008, p. 390). Similar developments have also been described for the Dutch parliament (Trouw Online, 2017).

Lastly, the analysis tested an effect of gender on being assigned to low-saliency committees, as was shown by several studies from diverse settings (Chiru, 2019; Espírito-Santo \& Sanches, 2020; Goodwin et al., 2020). Such patterns are not visible in the results of the two analysed parliaments. Although female MPs are still under-represented (after the 2021 election, 59 women and 91 men entered the House of Representatives; in the Chamber of Representatives, $41.3 \%$ of MPs are female), disproportionate clustering of female MPs in low-saliency areas is not visible. Of course, it might be that an analysis of other types of committees, e.g. those that deal with 'feminised' areas (Bolzendahl, 2014), can identify such patterns. 


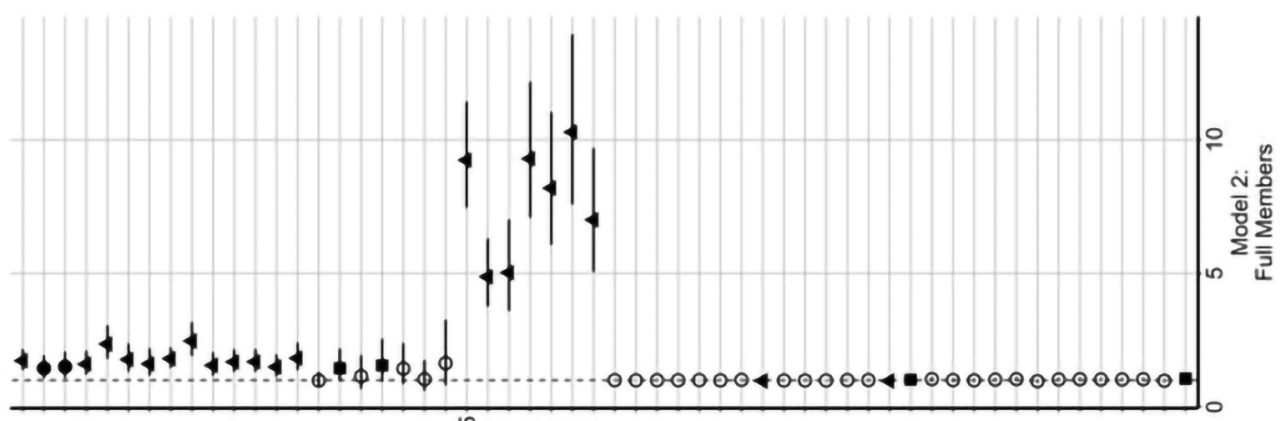

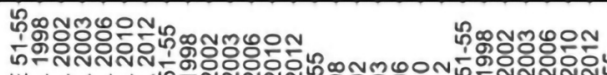

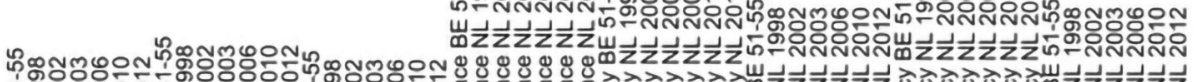

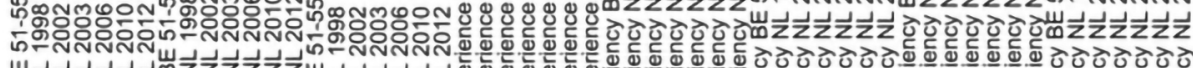
i.

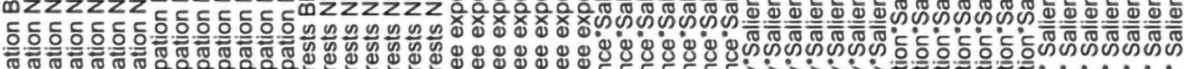

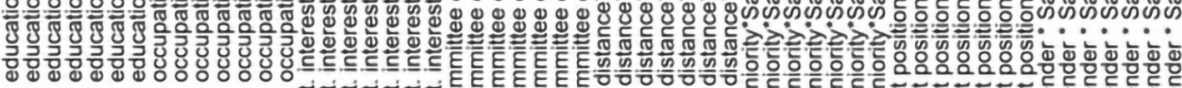

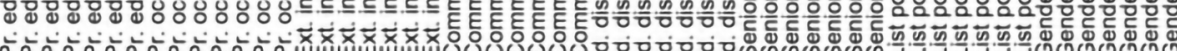

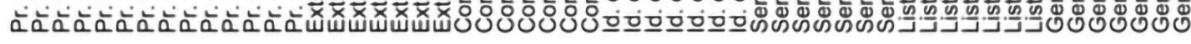

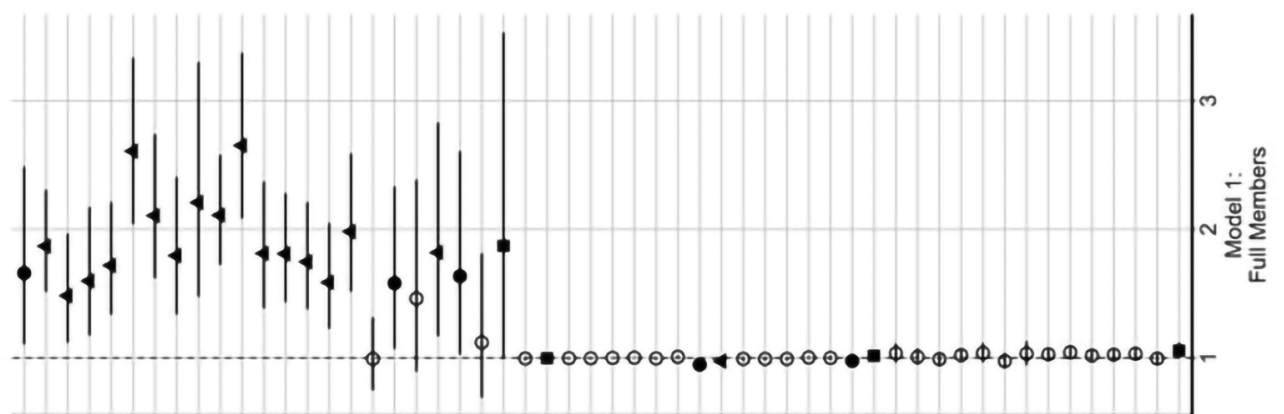

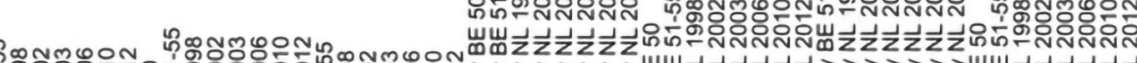

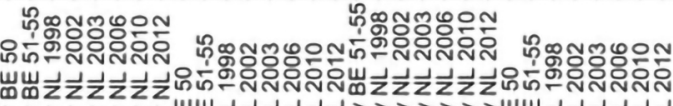

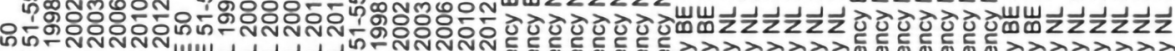
山س

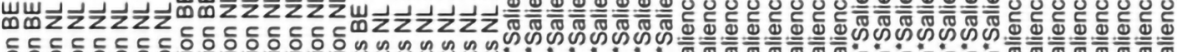

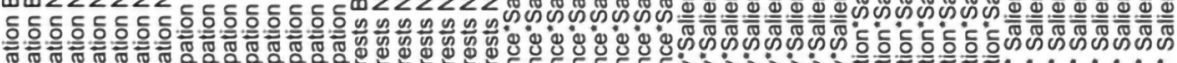
丹

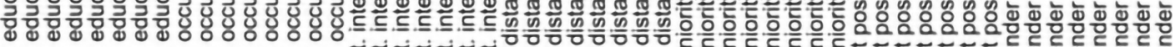

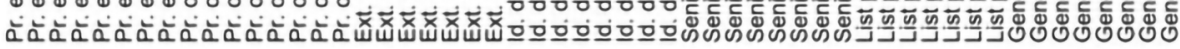

Symbols: empty circle $=\mathrm{p}>0.1$; black square $=\mathrm{p}<0.1$; black circle $=\mathrm{p}<0.05 ;$ black triangle $=\mathrm{p}<0.01$.

Figure 1 Odds ratios and confidence intervals of multiple membership, multilevel models Kamer van Volksvertegenwoordigers (1999-2019) and Dutch Tweede Kamer (1998-2017). Full members (including transfers). Left: Model 1 (without committee experience). Right: Model 2 (including committee experience). 

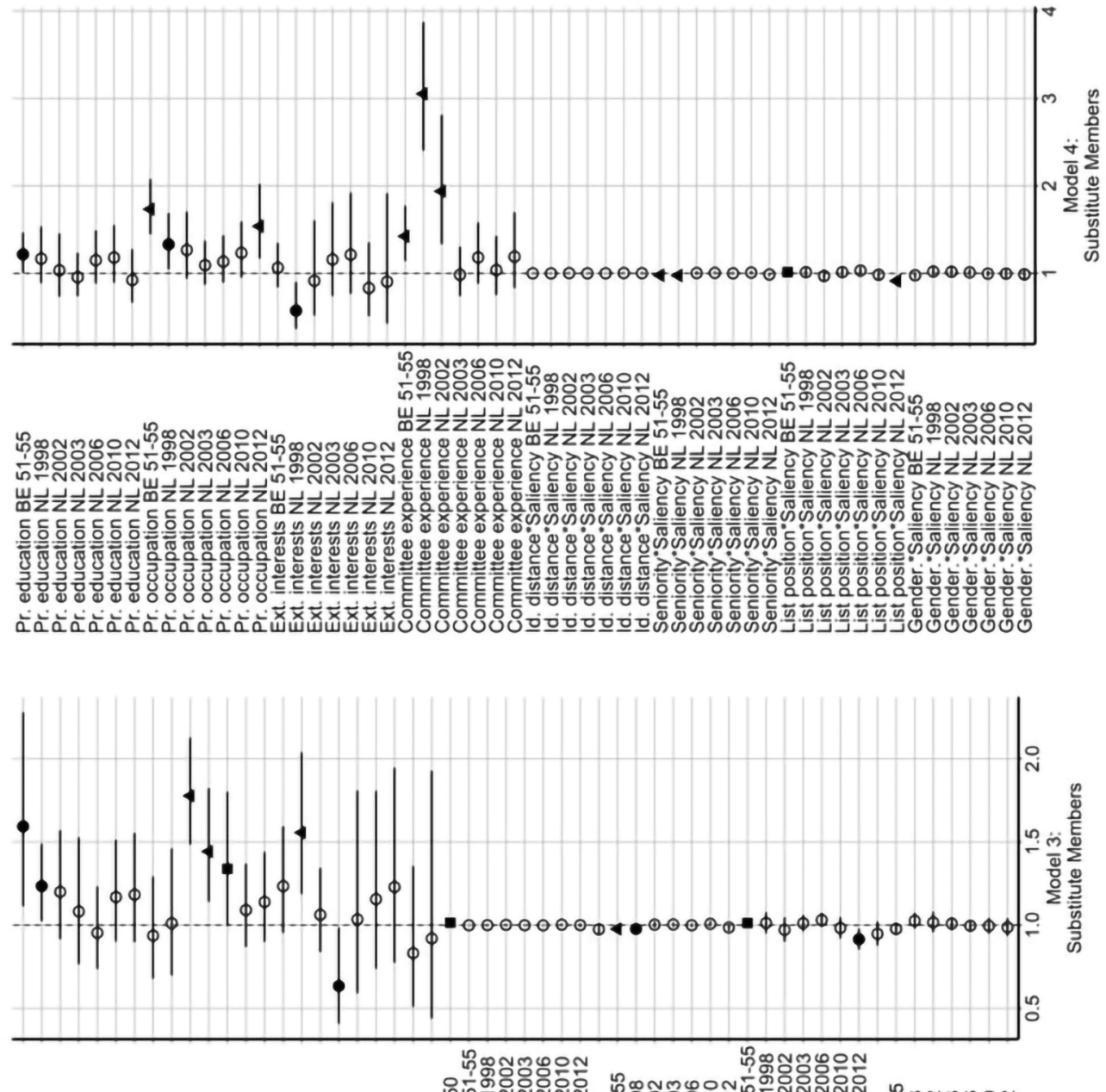

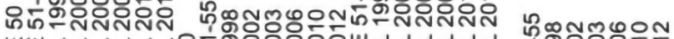

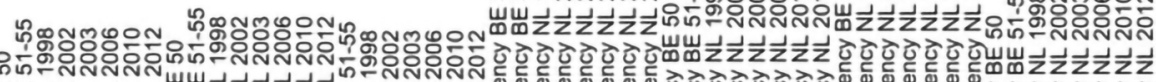

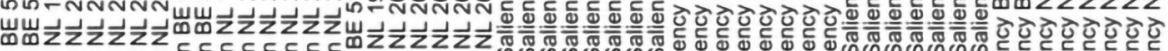

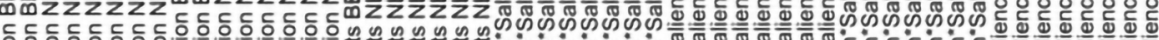

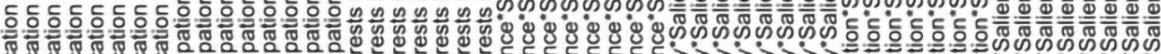

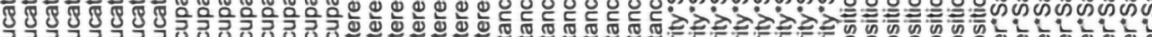

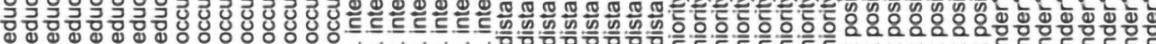

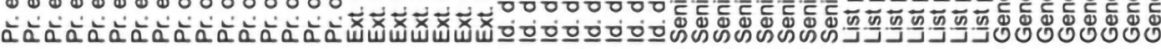

Symbols: empty circle $=\mathrm{p}>0.1$; black square $=\mathrm{p}<0.1$; black circle $=\mathrm{p}<0.05$; black triangle $=\mathrm{p}<0.01$.

Figure 2 Odds ratios and confidence intervals of multiple membership, multilevel models, Kamer van Volksvertegenwoordigers (1999-2019) and Dutch Tweede Kamer (1998-2017). Substitutes (including transfers). Left: Model 3 (without committee experience). Right: Model 4 (including committee experience). 


\section{Conclusion}

Parliaments around the world rely on committees, but the strength of committee systems varies greatly across parliaments. The question that guided the analysis was whether 'weaker' committees affect how parliamentary actors treat them. If committee work can meaningfully impact legislative proceedings, do PPGs and individual MPs give more consideration to assignments compared with weak committees? This article investigated this question by analysing the determinants of committee assignments in the Lower Houses of the two 'Low Countries': the Dutch House of Representatives (formally weak committees) and the Belgian Chamber of Representatives (formally strong committees). The article utilised congressional theories of legislative organisation to deduce hypotheses about factors that structure the assignment process. The analysis also tested the effect of gender on assignments to committees that deal with highly salient topics. The overarching question was whether these predictors would better explain assignments in the Belgian Chamber of Representatives than the House of Representatives.

The results indicate no difference concerning the presence of stable, reoccurring patterns between the two parliaments. Prior knowledge in a policy area, via MPs' educational or occupational background, greatly increases the likelihood of being assigned to a committee. Additionally, MPs often remain on the same committee in subsequent legislative periods. These findings are robust across legislative terms in both parliaments. In general, the analysis does not indicate a distributive or partisan logic of committee assignments. However, this conclusion does not imply a sidelining of the influence of PPGs. It is clear that even though the analysis stresses the role of MPs' knowledge in a subject area for their committee assignments, PPGs remain crucial actors. A striking difference was that committee assignments as substitute members in a stronger committee system are given due consideration. This provides some support for the argument that lower opportunity structures might lead actors to 'care less', but this only applies to the group of substitute members. However, more comparative research is needed from different institutional contexts.

Notwithstanding the difference regarding full and substitute members, the results suggest that committees, regardless of their comparative strength, are perceived by PPGs and individual MPs as important venues. Decisions on how to structure the workload in them are given careful consideration. It also serves as a reminder that the focus of 'formal' powers can misjudge the influence of committees. Committees in the House of Representatives may not have substantial redrafting rights but are active players in government control. Additionally, they can still exert 'passive' influence; research has suggested that bills are frequently amended or changed by the initiator (Visscher, 1994) during the committee stage, even though the committee members themselves cannot change them. 


\section{Notes}

1 The Rules of Procedure also prescribe the establishment of additional permanent committees for Digital Affairs, European Affairs and Kingdom Relations.

2 The two-minute debate was already laid down in the Rules of Procedure in 1998 (since 2021: Art. 7.31), but until 2021 the term verslag van een algemeen overleg (VAO) was used. In addition, there were reports of written (committee) meetings.

3 In practice, the proposal for the distribution is made in accordance with the PPG leaders.

4 In the current 55th legislative period, starting in 2019, this trend was discontinued.

5 There are also electoral districts in the Netherlands, but these have primarily an administrative function.

6 I would like to thank Marijn Nagtzaam for sharing his data with me.

7 An official website containing the results is available (http://www.ibzdgip.fgov.be/ result/nl/main.html), but it does not contain the list positions.

8 Treating all parties equally runs the risk of missing eventual theoretically interesting effects about distinctions of governing/opposition PPG or large PPGs. I estimated additional models for full members that include only opposition PPGs or large PPGs (here defined as PPGs whose size is greater than the number of committees). The results are available from the author on request. The results are fairly identical with the ones presented here in the article.

\section{References}

Andeweg, R. B. (2019). Consociationalism in the Low Countries: Comparing the Dutch and Belgian Experience. Swiss Political Science Review, 25(4), 408-425. doi: 10.1111/spsr. 12361.

André, A., Depauw, S. \& Martin, S. (2016). “Trust Is Good, Control Is Better" Multiparty Government and Legislative Organization. Political Research Quarterly, 69(1), 108-120. doi: 10.1177/1065912915623639.

Arwine, A., \& Mayer, L. (2013). The Changing Basis of Political Conflict in Advanced Western Democracies: The Politics of Identity in the United States, the Netherlands and Belgium. Palgrave Macmillan US. https://doi.org/10.1057/9781137306654

Baekgaard, M. \& Kjaer, U. (2012). The Gendered Division of Labor in Assignments to Political Committees: Discrimination or Self-Selection in Danish Local Politics? Politics \& Gender, 8, 465-482. doi: 10.1017/S1743923X12000499.

Bates, D., Maechler, M., Bolker, B. \& Walker, S. (2015). Ime4: Linear Mixed-effects Models Using Eigen and S4. R Package Version 1.1-8. http://cran.r-project.org/package=lme4.

Belgian Court of Audit. (2020). Publicaties Belgisch Staatsblad. www.ccrek.be/NL/ Mandaten/Archief.html.

Benoit, K., Watanabe, K., Wang, H., Nulty, P., Obeng, A., Müller, S. \& Matsuo, A. (2018). Quanteda: An R Package for the Quantitative Analysis of Textual Data. Journal of Open Source Software, 3(30), 774. doi: 10.21105/joss.00774.

Beretvas, S. N. (2011). Cross-Classified and Multiple- Membership Models. In J. J. Hox \& J. K. Roberts (Eds.), Handbook of Advanced Multilevel Analysis (pp. 313-335). Routledge. 
Bolzendahl, C. (2014). Opportunities and Expectations. Gender \& Society, 28(6), 847-876. doi: $10.1177 / 0891243214542429$.

Bovend'Eert, P. P. T. \& Kummeling, H. R. B. M. (2010). Het Nederlandse parlement . Kluwer.

Browne, W. J., Goldstein, H. \& Rasbash, J. (2001). Multiple Membership Multiple Classification (MMMC) Models. Statistical Modelling, 1(2), 103-124. doi: 10.1177/1471082X0100100202.

Chiru, M. (2019). Low-Cost Policy Specialisation, District Characteristics and Gender. Patterns of Committee Assignment in Romania. The Journal of Legislative Studies, 25(3), 375-393. doi: 10.1080/13572334.2019.1662608.

Cox, G. W. \& McCubbins, M. D. (1993). Legislative Leviathan: Party Government in the House. Cambridge University Press.

De Winter, L., Swyngedouw, M. \& Dumont, P. (2006). Party System(s) and Electoral Behaviour in Belgium: From Stability to Balkanisation. West European Politics, 29(5), 933-956. doi: 10.1080/01402380600968836.

Deschouwer, K. \& Reuchamps, M. (2013). The Belgian Federation at a Crossroad. Regional \& Federal Studies, 23(3), 261-270. doi: 10.1080/13597566.2013.773896.

Dutch Electoral Council. (1998). Uitslag Tweede Kamerverkiezing 1998. www.kiesraad.nl/ adviezen-en-publicaties/proces-verbalen/1998/05/proces-verbaal-uitslag-tweedekamerverkiezing-1998/proces-verbaal-uitslag-tweede-kamerverkiezing-1998.

Dutch Electoral Council. (2002). Uitslag Tweede Kamerverkiezing 2002. www.kiesraad.nl/ adviezen-en-publicaties/proces-verbalen/2002/05/proces-verbaal-uitslag-tweedekamerverkiezing-2002/proces-verbaal-uitslag-tweede-kamerverkiezing-2002.

Dutch Electoral Council. (2003). Uitslag Tweede Kamerverkiezing 2003. www.kiesraad.nl/ adviezen-en-publicaties/proces-verbalen/2003/01/27/proces-verbaal-zittingkiesraad-uitslag-tweede-kamerverkiezing-2003.

Dutch Electoral Council. (2006). Uitslag Tweede Kamerverkiezing 2006. www.kiesraad.nl/ adviezen-en-publicaties/proces-verbalen/2006/11/27/proces-verbaal-zittingkiesraad-uitslag-tweede-kamerverkiezing-2006.

Dutch Electoral Council. (2010). Uitslag Tweede Kamerverkiezing 2010. www.kiesraad.nl/ adviezen-en-publicaties/proces-verbalen/2010/06/16/proces-verbaal-tweedekamer-2010-kopie.

Dutch Electoral Council. (2012). Uitslag Tweede Kamerverkiezing 2012. www.kiesraad.nl/ adviezen-en-publicaties/proces-verbalen/2012/09/19/proces-verbaal-zitting-uitslagtweede-kamerverkiezing-2012.

Espírito-Santo, A. \& Sanches, E. R. (2020). Who Gets What? The Interactive Effect of MPs' Sex in Committee Assignments in Portugal. Parliamentary Affairs, 73(2), 450-472. doi: 10.1093/pa/gsz004.

Giannetti, D., Pedrazzani, A. \& Pinto, L. (2019). Personal Ambitions, Expertise and Parties' Control: Understanding Committee Assignment in the Italian Chamber of Deputies. Parliamentary Affairs, 72(1), 119-140. doi: 10.1093/pa/gsy013.

Goodwin, M., Holden Bates, S. \& McKay, S. (2020). Electing to Do Women's Work? Gendered Divisions of Labor in U.K. Select Committees, 1979-2016. Politics \& Gender, 1-33. doi: 10.1017/S1743923X19000874.

Gschwend, T. \& Zittel, T. (2018). Who Brings Home the Pork? Parties and the Role of Localness in Committee Assignments in Mixed-member Proportional Systems. Party Politics, 24(5), 488-500. doi: 10.1177/1354068816678884.

Hansen, M. E. (2019). Distributing Chairs and Seats in Committees: A Parliamentary Perspective. Parliamentary Affairs, 72(1), 202-222. doi: 10.1093/pa/gsy008. 
International Labour Office. (2012). International Standard Classification of Occupations: Structure, Group Definitions and Correspondence Tables. www.ilo.org/public/english/ bureau/stat/isco/docs/publication08.pdf.

Krehbiel, K. (1992). Information and Legislative Organization. University of Michigan Press.

Laver, M., Benoit, K. \& Garry, J. (2003). Extracting Policy Positions from Political Texts Using Words as Data. American Political Science Review, 97(2), 311-331. doi: 10.1017/ S0003055403000698.

Leighton, W. A. \& Lopez, E. J. (2002). Committee Assignments and the Cost of Party Loyalty. Political Research Quarterly, 55(1), 59. doi: 10.2307/3088066.

Lijphart, A. (1977). Democracy in Plural Societies: A Comparative Explanation. Yale University Press.

Martin, L. W. \& Vanberg, G. (2020). Coalition Government, Legislative Institutions, and Public Policy in Parliamentary Democracies. American Journal of Political Science, 64(2), 325-340. doi: 10.1111/ajps.12453.

Martin, S. (2014). Committees. In T. Saalfeld, S. Martin \& K. Strøm (Eds.), Oxford Handbook of Legislative Studies (pp. 352-368). Oxford University Press.

Martin, S. \& Mickler, T. (2019). Committee Assignments: Theories, Causes and Consequences. Parliamentary Affairs, 72(1). doi: 10.1093/pa/gsy015.

Mayhew, D. R. (1974). Congress: The Electoral Connection. Yale University Press.

Mickler, T. A. (2017). Committee Autonomy in Parliamentary Systems - Coalition Logic or Congressional Rationales? The Journal of Legislative Studies, 23(3), 367-391. doi: 10.1080/13572334.2017.1359941.

Mickler, T. A. (2018a). Not So Random after All? - Revisiting Committee Assignments in Dáil Éireann. Irish Political Studies, 33(1), 112-135. doi: 10.1080/07907184.2017.1325361.

Mickler, T. A. (2018b). Who Gets What and Why? Committee Assignments in the German Bundestag. West European Politics, 41(2), 517-539. doi: 10.1080/01402382.2017.1359461.

Mickler, T. A. (2019). Who Goes Where? Committee Assignments in the Dutch Tweede Kamer. Parliamentary Affairs, 72(1), 99-118. doi: 10.1093/pa/gsy011.

Murray, R. \& Sénac, R. (2018). Explaining Gender Gaps in Legislative Committees. Journal of Women, Politics \& Policy, 39(3), 310-335. doi: 10.1080/1554477X.2018.1477397.

Nagtzaam, M. A. (2019). Second-order Electoral Personalization. Intra-party Preference Voting in Belgium and the Netherlands. Leiden University.

Pansardi, P. \& Vercesi, M. (2017). Party Gate-keeping and Women's Appointment to Parliamentary Committees: Evidence from the Italian Case. Parliamentary Affairs, 70(1), 62-83. doi: 10.1093/pa/gsv066.

Raymond, C. D., \& Holt, J. (2018). Constituency Preferences and Assignment to Agriculture Committees. Parliamentary Affairs, 72(1), 141-161. https://doi.org/10.1093/pa/ gsy012

Raymond, C. D. \& Juárez, S. B. (2019). Constituency Preferences and Committee Selection in the Mexican Cámara de Diputados. Latin American Politics and Society, 61(04), 95-117. doi: 10.1017/lap.2019.26.

Rules of Procedure Chamber of Representatives. (2020). Version Date: December 2020. www.dekamer.be/kvvcr/pdf_sections/publications/reglement/reglementNL.pdf.

Rules of Procedure House of Representatives. (2021). Version Date: 25 February 2021. www.tweedekamer.nl/sites/default/files/atoms/files/rvo_miniboekje_maart_ 2021_0.pdf.

Shepsle, K. A. (1978). The Giant Jigsaw Puzzle: Democratic Committee Assignments in the Modern House. University of Chicago Press. 
Staelraeve, S. (2003). Parlementaire onderzoekscommissies: zin en onzin . Academia Press.

Strøm, K. (1998). Parliamentary Committees in European Democracies. The Journal of Legislative Studies, 4(1), 21-59. doi: 10.1080/13572339808420538.

Timmermans, A. \& Moury, C. (2006). Coalition Governance in Belgium and The Netherlands: Rising Government Stability Against All Electoral Odds. Acta Politica, 41(4), 389-407. doi: 10.1057/palgrave.ap.5500139.

Trouw Online. (2017). Er zit te weinig ervaring in nieuwe Kamer. www.trouw.nl/nieuws/erzit-te-weinig-ervaring-in-nieuwe-kamer b6aaeb16/.

Tweede Kamer. (2021). Openbare registers (nevenfuncties, geschenken, reizen). www.tweedekamer.nl/kamerleden_en_commissies/openbare_registers.

Verleden, F. \& Heyneman, C. (2008). Parlementaire circulatie in de Belgische Kamer van volksvertegenwoordigers, 1831-2008. Res Publica, 4, 383-408. doi: 10.5553/RP/ 048647002008050004002.

Visscher, G. (1994). Parlementaire invloed op wetgeving: Inventarisatie en analyse van de invloed van de beide Kamers der Staten-Generaal op de wetgevende activiteiten van de kabinetten-Marijnen tot en met-Lubbers I . SDU Uitg. Koninginnegracht.

Volkens, A., Burst, T., Krause, W., Lehmann, P., Theres, M., Merz, N., Regel, S., Weßels, B. \& Zehnter, L. (2020). The Manifesto Data Collection. Manifesto Project (MRG/CMP/ MARPOR). Version 2020b. Wissenschaftszentrum Berlin Für Sozialforschung (WZB). https://manifestoproject.wzb.eu/ .

Wagner, M. \& Meyer, T. M. (2014). Which Issues Do Parties Emphasise? Salience Strategies and Party Organisation in Multiparty Systems. West European Politics, 37(5), 1019-1045. doi: 10.1080/01402382.2014.911483.

Yordanova, N. (2009). The Rationale Behind Committee Assignment in the European Parliament: Distributive, Informational and Partisan Perspectives. European Union Politics, 10(2), 253-280. doi: 10.1177/1465116509103377.

Zubek, R. (2015). Coalition Government and Committee Power. West European Politics, 38(5), 1020-1041. doi: 10.1080/01402382.2015.1045322.

Zubek, R. (2020). Committee Strength in Parliamentary Democracies: A New Index. European Journal of Political Research. doi: 10.1111/1475-6765.12426.

\section{Appendices}

\section{Appendix 1}

List of analysed committees: Belgium

Legislative period 50 (1999-2003), 51 (2003-2007), 52 (2007-2010), 53 (2010-2014) and 54 (2014-2019)

- Commission des Affaires sociales/Commissie voor de Sociale Zaken

- Commission de la Défense nationale/Commissie voor de Landsverdediging

- Commission chargée des Problèmes de Droit commercial et économique/ Commissie belast met de problemen inzake Handels- en Economisch Recht

- Commission de l'Economie, de la Politique scientifique, de l'Education, des Institutions scientifiques et culturelles nationales, des Classes moyennes et de l'Agriculture/Commissie voor het Bedrijfsleven, het Wetenschapsbeleid, het Onderwijs, de Nationale Wetenschappelijke en Culturele Instellingen, de Middenstand en de Landbouw 
- Commission des Finances et du Budget/Commissie voor de Financiën en de Begroting

- Commission de l'Infrastructure, des Communications et des Entreprises publiques Commissie voor de Infrastructuur, het Verkeer en de Overheidsbedrijven

- Commission de l'Intérieur, des Affaires générales et de la Fonction publique/ Commissie voor de Binnenlandse Zaken, de Algemene Zaken en het Openbaar Ambt

- Commission de la Justice/Commissie voor de Justitie

- Commission des Relations extérieures/Commissie voor de Buitenlandse Betrekkingen

- Commission de Révision de la Constitution et de la Réforme des Institutions/ Commissie voor de Herziening van de Grondwet en de Hervorming van de Instellingen

- Commission de la Santé publique, de l'Environnement et du Renouveau de la Société/Commissie voor de Volksgezondheid, het Leefmilieu en de Maatschappelijke Hernieuwing

\section{Appendix 2}

List of analysed committees: the Netherlands 1998/2002

- Binnenlandse Zaken en Koninkrijksrelaties

- Buitenlandse Zaken

- Defensie

- Economische Zaken

- Europese Zaken

- Landbouw, Natuurbeheer en Visserij

- Financiën

- Justitie

- Onderwijs, Cultuur en Wetenschappen

- Nederlands-Antilliaanse en Arubaanse Zaken

- Rijksuitgaven

- Sociale Zaken en Werkgelegenheid

- Volksgezondheid, Welzijn en Sport

- Volkshuisvesting, Ruimtelijke Ordening en Milieubeheer

- Verkeer en Waterstaat

2003

- Binnenlandse Zaken en Koninkrijksrelaties

- Buitenlandse Zaken

- Defensie

- Economische Zaken

- Europese Zaken

- Landbouw, Natuurbeheer en Visserij 
- Financiën

- Justitie

- Onderwijs, Cultuur en Wetenschappen

- Nederlands-Antilliaanse en Arubaanse Zaken

- Rijksuitgaven

- Sociale Zaken en Werkgelegenheid

- Volksgezondheid, Welzijn en Sport

- Volkshuisvesting, Ruimtelijke Ordening en Milieubeheer

- Verkeer en Waterstaat

- Integratiebeleid (AC)

2006

- Binnenlandse Zaken en Koninkrijksrelaties

- Buitenlandse Zaken

- Defensie

- Economische Zaken

- Europese Zaken

- Landbouw, Natuurbeheer en Visserij

- Financiën

- Justitie

- Onderwijs, Cultuur en Wetenschappen

- Nederlands-Antilliaanse en Arubaanse Zaken

- Rijksuitgaven

- Sociale Zaken en Werkgelegenheid

- Volksgezondheid, Welzijn en Sport

- Volkshuisvesting, Ruimtelijke Ordening en Milieubeheer

- Verkeer en Waterstaat

- Jeugdzorg (AC)

- Wonen, Wijken en Integratie (AC)

2010

- Binnenlandse Zaken

- Buitenlandse Zaken

- Defensie

- Economische Zaken, Landbouw en Innovatie

- Europese Zaken

- Financiën

- Infrastructuur en Milieu

- Koninkrijkrelaties

- Onderwijs, Cultuur en Wetenschappen

- Rijksuitgaven

- Sociale Zaken en Werkgelegenheid

- Veiligheid en Justitie

- Verkeer en Waterstaat

- Volksgezondheid, Welzijn en Sport

- Jeugdzorg $(\mathrm{AC})$ 
- Immigratie en Asiel (AC)

2012

- Binnenlandse Zaken

- Buitenlandse Zaken

- Defensie

- Economische Zaken

- Europese Zaken

- Financien

- Infrastructuur en Milieu

- Koninkrijkrelaties

- Onderwijs, Cultuur en Wetenschappen

- Rijksuitgaven

- Sociale Zaken en Werkgelegenheid

- Veiligheid en Justitie

- Volksgezondheid, Welzijn en Sport

- Wonen en Rijksdienst (AC)

- Buitenlandsehandel en Ontwikkelingssamenwerking (AC)

Table 2 Model Summaries Committee Assignments (Including Transfers) in the Belgian Kamer van Volksvertegenwoordigers 1999-2019, Full Members

\begin{tabular}{|c|c|c|c|}
\hline & \multirow{2}{*}{$\begin{array}{r}50 \text { th } \\
(\text { '99-'03) } \\
\text { Model I }\end{array}$} & \multicolumn{2}{|c|}{5 I st to 54th ('03-'19) } \\
\hline & & Model I & Model 2 \\
\hline \multirow[t]{2}{*}{ Prior education } & $0.506^{* *}$ & $0.625 * * *$ & $0.547 * * *$ \\
\hline & $(0.207)$ & $(0.108)$ & $(0.113)$ \\
\hline \multirow[t]{2}{*}{ Prior occupation } & $0.792 * * *$ & $0.746 * * *$ & $0.590 * * *$ \\
\hline & $(0.205)$ & $(0.103)$ & $(0.108)$ \\
\hline \multirow[t]{2}{*}{ External interest } & & -0.009 & -0.017 \\
\hline & & $(0.144)$ & $(0.150)$ \\
\hline \multirow[t]{2}{*}{ Committee experience } & & & $2.223 * * *$ \\
\hline & & & $(0.109)$ \\
\hline \multirow[t]{2}{*}{ High importance committee (CMP rank) } & 0.088 & 0.024 & 0.016 \\
\hline & $(0.060)$ & $(0.029)$ & $(0.029)$ \\
\hline \multirow[t]{2}{*}{ Ideological distance to PPG (WS) } & 0.047 & 0.011 & 0.008 \\
\hline & $(0.058)$ & $(0.011)$ & $(0.012)$ \\
\hline \multirow[t]{2}{*}{ Number LPs. } & 0.222 & $0.156 * * *$ & 0.047 \\
\hline & $(0.15 I)$ & $(0.048)$ & $(0.053)$ \\
\hline \multirow[t]{2}{*}{ Relative list position } & & $-0.128^{*}$ & $-0.146 * *$ \\
\hline & & $(0.067)$ & $(0.070)$ \\
\hline \multirow[t]{2}{*}{ Gender } & -0.118 & -0.167 & -0.176 \\
\hline & $(0.3 \mid 5)$ & $(0.157)$ & $(0.165)$ \\
\hline
\end{tabular}


Table 2 (Continued)

\begin{tabular}{|c|c|c|c|}
\hline & \multirow{2}{*}{$\begin{array}{r}50 \text { th } \\
(' 99-' 03) \\
\text { Model I }\end{array}$} & \multicolumn{2}{|c|}{5 I st to 54th ('03-'।9) } \\
\hline & & Model I & Model 2 \\
\hline \multirow[t]{2}{*}{ Ideological distance * HICs } & -0.006 & $-0.003^{*}$ & -0.002 \\
\hline & $(0.009)$ & $(0.002)$ & $(0.002)$ \\
\hline \multirow[t]{2}{*}{ Number LPs. * HICs } & $-0.055^{* *}$ & $-0.026 * * *$ & $-0.028 * * *$ \\
\hline & $(0.023)$ & $(0.007)$ & $(0.008)$ \\
\hline \multirow[t]{2}{*}{ Rel. list pos. * HIC } & & $0.016^{*}$ & $0.017^{*}$ \\
\hline & & $(0.009)$ & $(0.010)$ \\
\hline \multirow[t]{2}{*}{ Gender * HIC } & 0.032 & 0.027 & 0.022 \\
\hline & $(0.046)$ & $(0.023)$ & $(0.024)$ \\
\hline \multirow[t]{2}{*}{ Constant } & $-2.548 * * *$ & $-2.302 * * *$ & $-2.193 * * *$ \\
\hline & $(0.402)$ & $(0.212)$ & $(0.219)$ \\
\hline \multicolumn{4}{|l|}{ Random effects (Std. Dev.) } \\
\hline Individual MPs & 0.000 & 0.000 & 0.000 \\
\hline Committees & 0.000 & 0.159 & 0.135 \\
\hline Parties & 0.000 & 0.223 & 0.262 \\
\hline Legislative periods & & 0.045 & 0.087 \\
\hline Observations & 1,716 & 7,227 & 7,227 \\
\hline Log Likelihood & -644.752 & $-2,764.308$ & $-2,562.144$ \\
\hline Akaike Inf. Crit. & $\mathrm{I}, 3 \mathrm{I} 5.505$ & $5,562.615$ & $5,160.287$ \\
\hline
\end{tabular}

Note: ${ }^{*} \mathrm{p}<0.1$; ${ }^{* *} \mathrm{p}<0.05$; *** $\mathrm{p}<0.01$. Standard errors in parentheses. Model I excluding committee experience; Model 2 including committee experience 


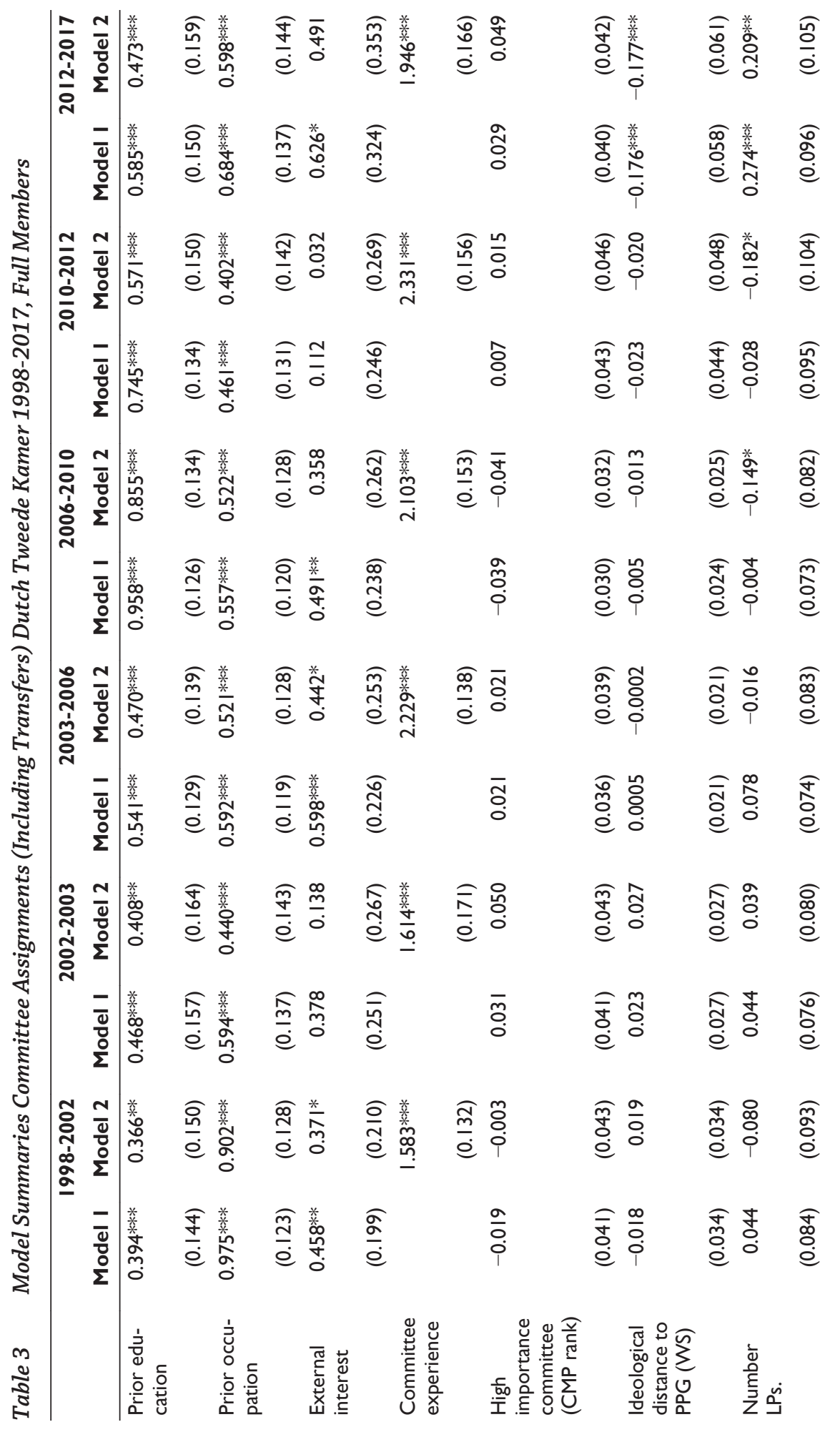


The Determinants of Committee Membership in Belgium and the Netherlands

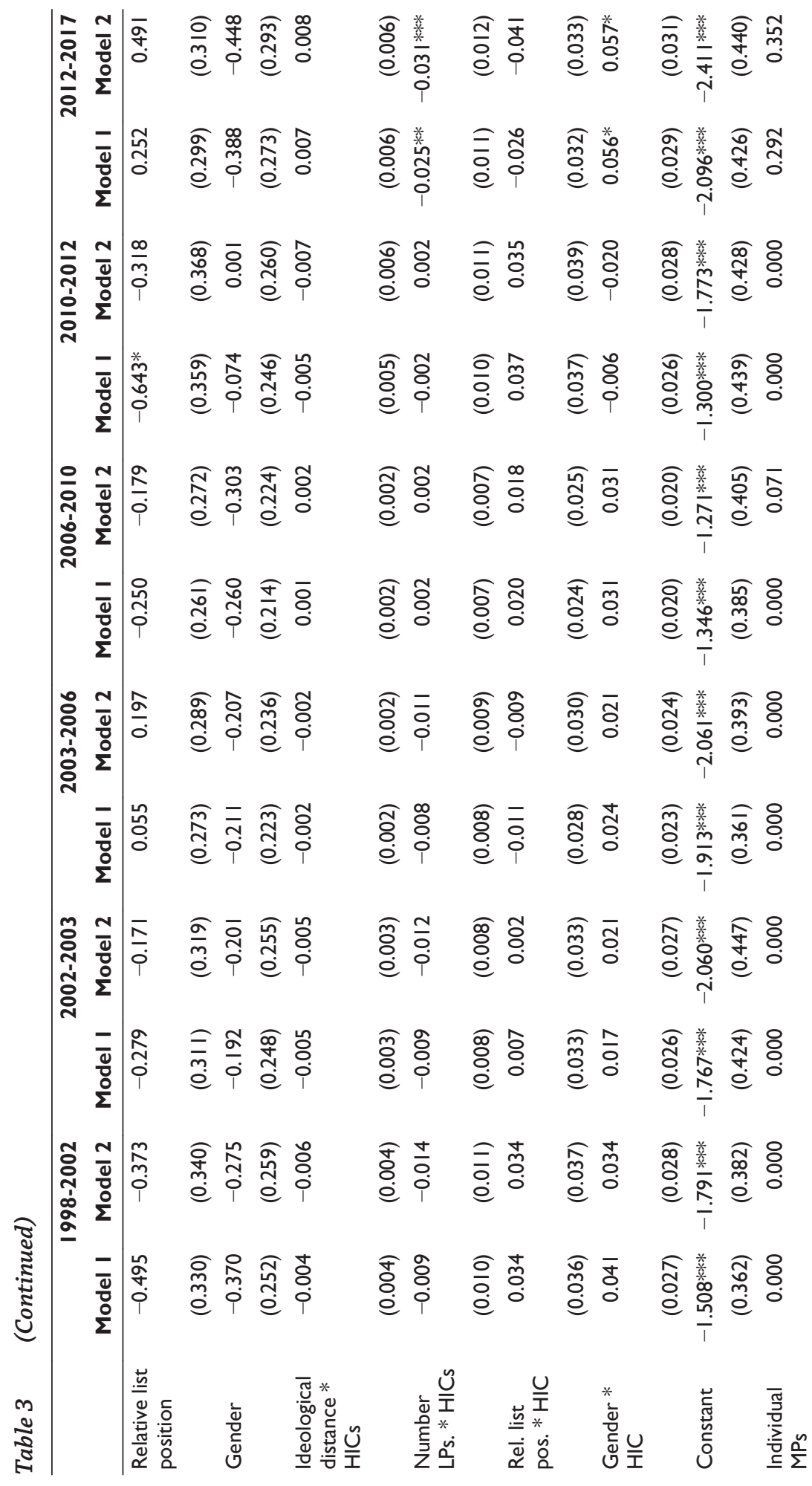




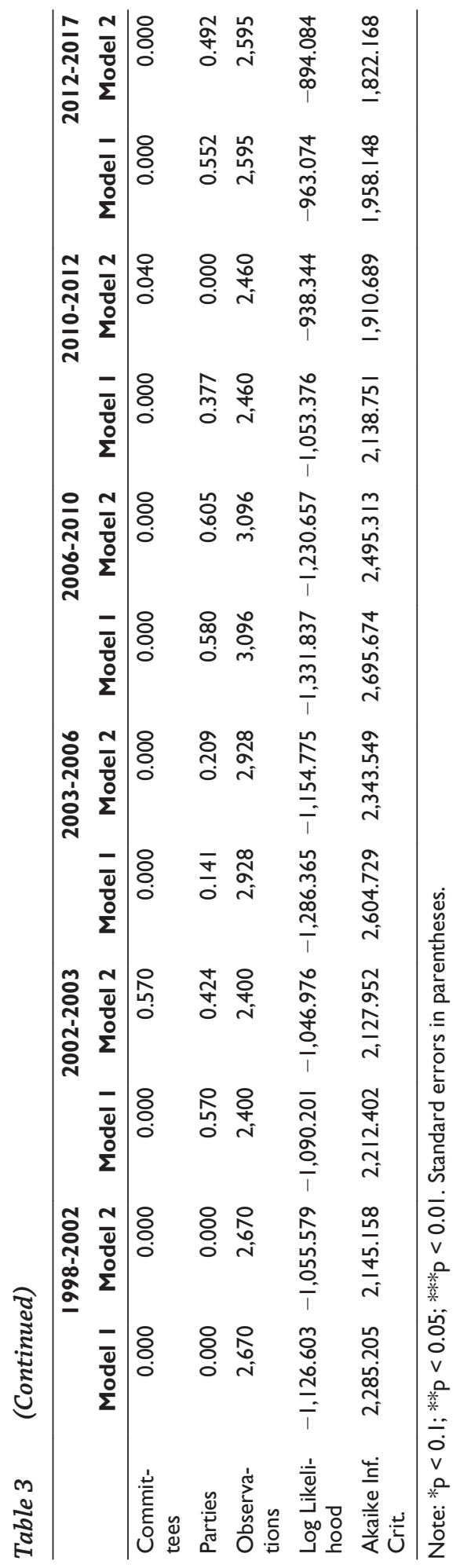


Table 4 Model Summaries Committee Assignments (Including Transfers) in the Belgian Kamer van Volksvertegenwoordigers 1999-2019, Substitute Members

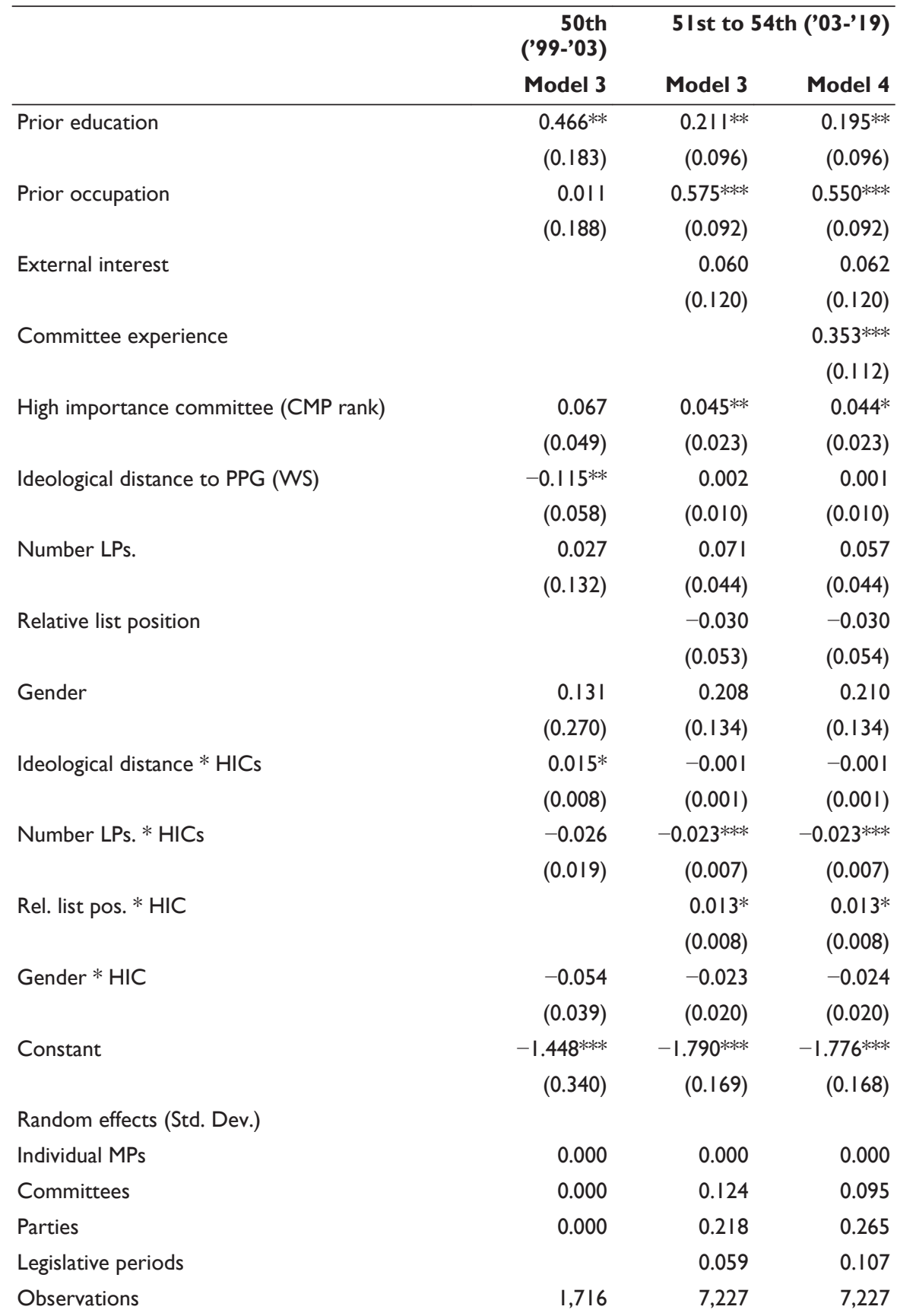


Tim Mickler

Table 4 (Continued)

\begin{tabular}{lrrr}
\hline & 50th & 5 I st to 54th ('03-'19) \\
& $\begin{array}{l}\text { ('99-'03) } \\
\text { Model 3 }\end{array}$ & Model 3 & Model 4 \\
\hline Log Likelihood & -868.481 & $-3,545.434$ & $-3,540.685$ \\
Akaike Inf. Crit. & $1,762.962$ & $7,124.868$ & $7,117.369$ \\
\hline
\end{tabular}

Note: ${ }_{p}<0.1 ;{ }^{* *} p<0.05 ;{ }^{* *} p<0.01$. Standard errors in parentheses. 


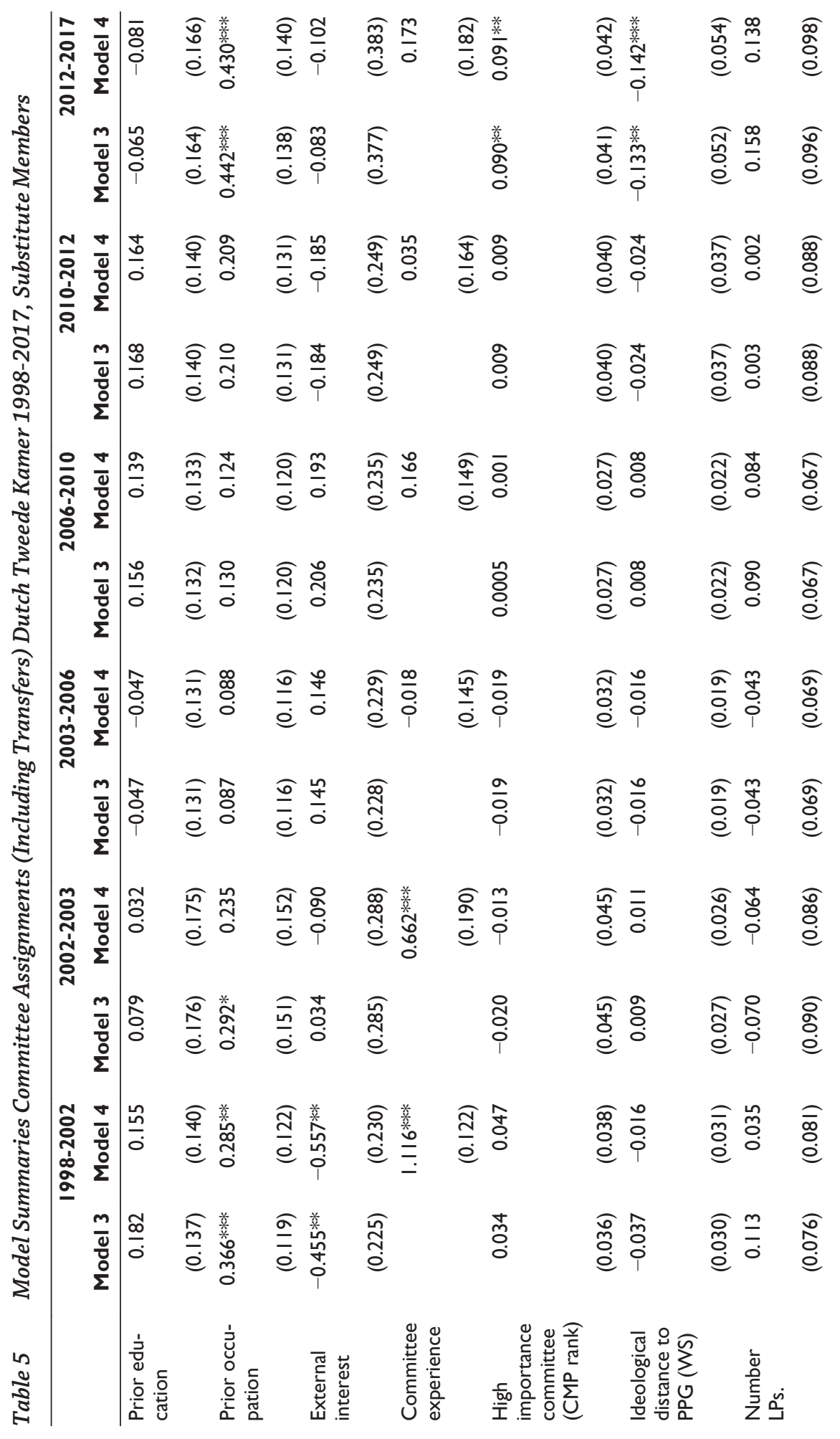




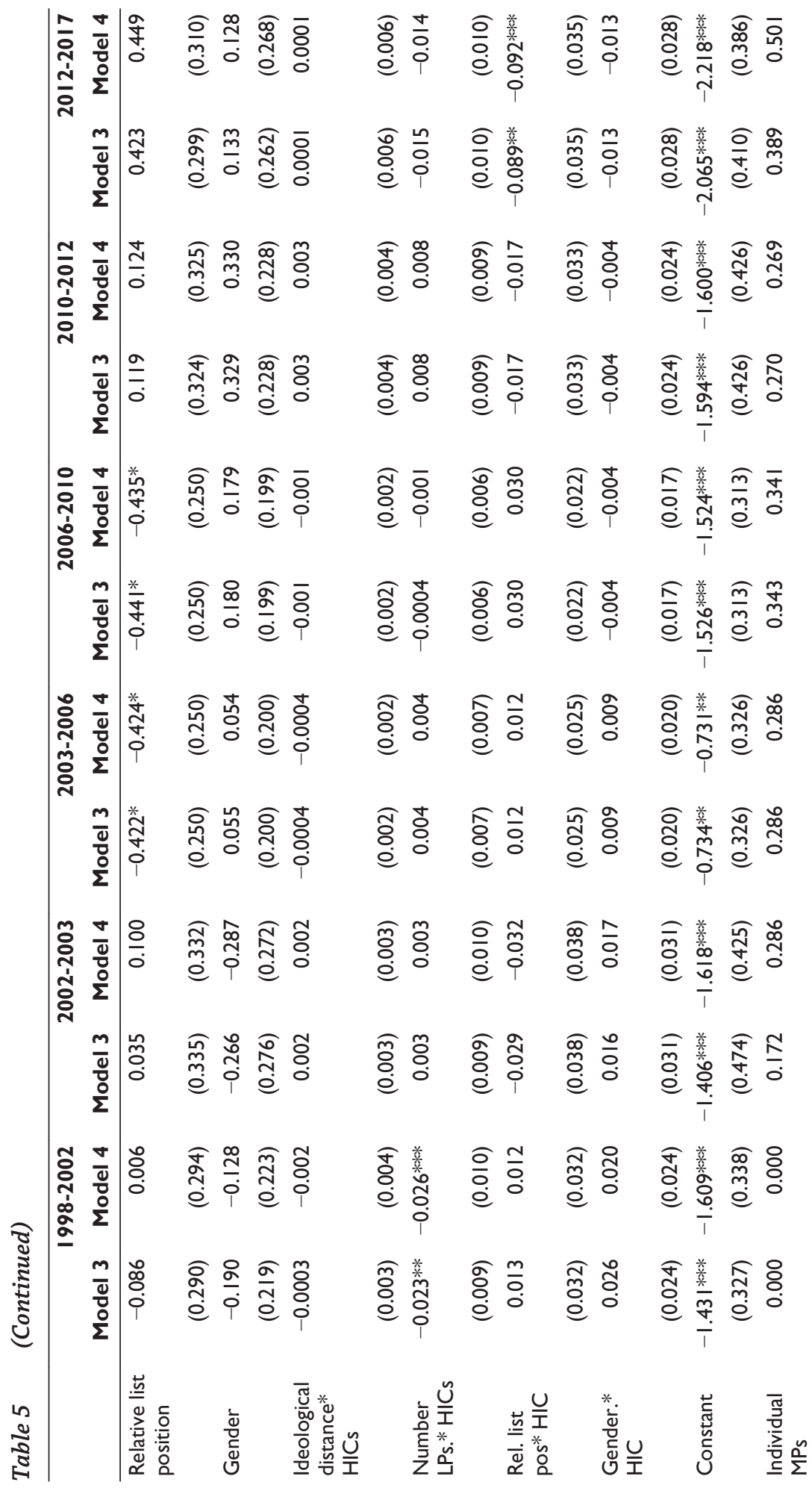


The Determinants of Committee Membership in Belgium and the Netherlands

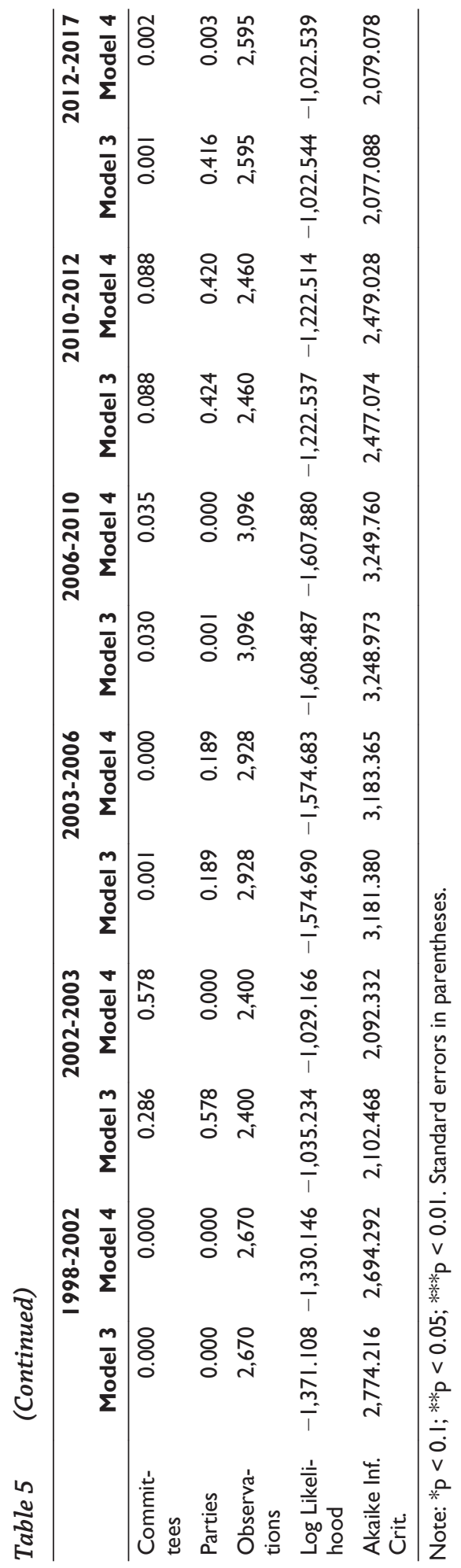

